University of South Florida

DIGITAL COMMONS

Digital Commons @ University of

@ UNIVERSITY OF SOUTH FLORIDA

South Florida

Rehabilitation and Mental Health Counseling

Faculty Publications

Rehabilitation and Mental Health Counseling

2008

\title{
Communication Technology Changes how We Age
}

J. L. Fozard

William D. Kearns

University of South Florida, kearns@usf.edu

Follow this and additional works at: https://digitalcommons.usf.edu/mhs_facpub

\section{Scholar Commons Citation}

Fozard, J. L. and Kearns, William D., "Communication Technology Changes how We Age" (2008).

Rehabilitation and Mental Health Counseling Faculty Publications. 26.

https://digitalcommons.usf.edu/mhs_facpub/26

This Article is brought to you for free and open access by the Rehabilitation and Mental Health Counseling at Digital Commons @ University of South Florida. It has been accepted for inclusion in Rehabilitation and Mental Health Counseling Faculty Publications by an authorized administrator of Digital Commons @ University of South Florida. For more information, please contact digitalcommons@usf.edu. 
J.L. Fozard, W.D. Kearns. Communication technology changes how we age. Gerontechnology 2008; 7(2):106. Gerontechnology is an interdisciplinary field that combines research on the sciences underpinning technology and aging to achieve optimal technical environments for aging and aged people. Of the six technical disciplines most directly involved in Gerontechnology--chemistry, architecture, communication, mechatronics (robotics), ergonomics, business management-communication is directly or indirectly involved in more areas of technologically supported environments--health, everyday living, transportation, work and leisure--than any of the others ${ }^{1, \text { Table } 1}{ }^{1}$. The paper will selectively review the research on communication and aging with special attention to how these technologies improve: acceptance and use of communication technology; communication between people; between people and machine generated information; and the use of direct communications between machines and people to influence or direct human behavior. Special attention will be given to the role of high speed networking and embedded technologies in creating new dimensions of communication between people and machines ${ }^{2}$. Methods Overcoming age associated limitations in perceptual motor and cognitive function ${ }^{3}$ : (i) Display/control, (ii) Technology generations, (iii) Training, situated learning, (iv) Motivational factors in adopting new technology. Improving communication between people: (i) Remote behavioral and physiological monitoring of persons-security, accidents, etc., (ii) Teleconferencing, (iii) Visual and auditory enhancers. Improving communication between people and machine generated information: (i) Ergonomics of web pages, computer displays and small visual displays, (ii) Slowing of speech in TV broadcasts. Direct communications between people and machines: (i) Service robots, (ii) Spoken and visual information to provide information, e.g., GPS wayfinding systems ${ }^{4}$, (iii) Machine coaching for nutritional guidance and exercise and fitness training, (iv) Combining location-aware technology with machine generated directions and advice. Results and discussion Research and development activities for the last topic are more recent and less well known than the other three; accordingly more attention will be given to them.

\section{References}

1. Bouma H, Fozard J L, Bouwhuis DG, Taipale V. Gerontechnology 2007;6:190-216

2. Kearns WD, Fozard J L. Gerontechnology 2007;6:135-146

3. Fozard J L, Kearns WD. In Gerontechnology. S pringfield: Thomas; 2007; pp 271-291

4. Fitzgerald M. New York Times, J an.27, 2008, Sunday Business, p 16

Keywords: care support and organization, human machine communication

Address: University of South Florida, USA; E: fozard@ tampabay.rr.com 